ANALELE UNIVERSITĂTIII DIN BUCUREȘTI - SERIA DREPT

\title{
Implicațiile Deciziei RIL X(10)/2005 asupra recidivei și asupra modalității de sancționare a concursului de infracțiuni în cazul grațierii antecondamnatorii
}

\section{Tudor-Andrei Chițimia}

Student, Anul III

Facultatea de Drept, Universitatea din București

Rezumat: Prezenta cercetare urmărește să analizeze efectele produse în materia grațierii și a pluralității de infracțiuni de către Decizia X(10)/2005 a Înaltei Curți de Casație și Justiție. Cu toate că modul de sancționare a concursului de infracțiuni stabilit de aceasta pare echitabil din punct de vedere al condamnatului, beneficiul adus de pe urma grațierii se dublează, astfel, în mod nejustificat. În acest sens, grațierea antecondamnatorie ar înlătura și ierta și o eventuală stare de recidivă, pe lângă remiterea executării pedepsei aplicate de către instanța de judecată. Drept urmare, va fi adus în discuție un principiu conceput de doctrina penală mai veche, urmând ca argumentele în favoarea acestuia să fie coroborate cu alte opinii doctrinare în materie și cu diverse hotărâri ale instanțelor naționale. Acestea vor fi realizate cu scopul de a propune o posibilă soluție de rezolvare a acestei probleme de drept care să respecte efectele pe care le poate produce grațierea în mod legal. Ulterior, vom compara situația premisă și cu unele ipoteze particulare care se pot ivi în practică. În final, vom prezenta și o altă jurisprudență obligatorie a instanței supreme care se află în contradicție cu decizia de la care a plecat ipoteza articolului.

Cuvinte cheie: grațiere antecondamnatorie; recidivă; concurs de infracțiuni; pedeapsă rezultantă; recontopire; principiul individualizării depline a pedepsei.

The implications of the Decision RIL $X(10) / 2005$ on recidivism and on the modality of sanctioning the concurrent crimes in case of prior pardon

Abstract: This research seeks to analyse the effects produced in matters of pardon and plurality of crimes by the High Court of Cassation and Justice's Decision X(10)/2005. Although the modality of sanctioning the concurrent crimes established by the supreme court seems fair from the convict's point of view, the benefit resulted from the pardon is doubled in an unjustified manner. This way, the prior pardon would also remove an eventual state of recidivism, besides the forgiveness of the punishment's execution applied by the court. As a result, it will be brought up for discussion a principle created by the criminal law's older literature, followed by the corroboration between the arguments in favour of this principle, the other opinions of the criminal law's literature in this matter and some national courts decisions. These will be done with the purpose to suggest a possible solution for solving this law issue which respects the effects that pardon can legally produce. Later, we will also compare this problematic with some particular hypotheses which can occur in 
practice. In the end, we will present another mandatory jurisprudence of the supreme court which is in contradiction with the decision from which the assumption of this article was made.

Key words: prior pardon; recidivism; concurrent crimes; resultant punishment; remerge; the principle of complete individualization of the punishment.

\section{INTRODUCERE}

Scurt istoric. Grațierea reprezintă una dintre instituțiile dreptului penal care are atât o componentă de ordin juridic, cât și una de ordin moral. Aceasta a fost numită în doctrina mai veche remitere, comutare sau iertare de pedeapsă ${ }^{1}$. Încă din antichitate, aceasta a constituit un mijloc de putere discreționară pe care o aveau la îndemână conducătorii acelor timpuri atât față de lege, cât și față de autoritatea judecătorească existentă atunci ${ }^{2}$. Beccaria afirma că "grațierea reprezintă acea virtute care a fost uneori pentru suverani înlocuitorul tuturor acelor calități trebuitoare pentru îndeplinirea îndatoririlor tronului". După părerea acestuia, grațierea este "cel mai frumos" și „cel mai de dorit atribut al tronului" ${ }^{3}$. Neajunsul subiectivismului cu care putea fi impregnată această instituție de drept conducea de cele mai multe ori la o anumită nemulțumire și îngrijorare din partea societății. Cu toate acestea, acest atribut exclusiv al conducătorilor statelor s-a conservat de-a lungul secolelor, până în zilele noastre ${ }^{4}$.

Caracterul neschimbător al grațierii a creat, în actualele sisteme de drept, o suită de probleme în legătură cu efectele pe care aceasta le produce. De asemenea, eventuala discriminare și posibilitatea de a răsturna, într-o anumită măsură, autoritatea de lucru judecat a instanțelor judecătorești a reprezentat un obstacol în supraviețuirea acestei instituții. Chiar dacă dintotdeauna a reprezentat o măsură de excepție oferită din partea statului, grațierea a condus la o bogată jurisprudență a instanțelor naționale și la o vastă analiză doctrinară. În perioada în care era în vigoare Codul penal din 1969, majoritatea autorilor emeriți ai dreptului penal s-au aplecat asupra acestei instituții. Acest fapt s-a datorat, în genere, decretelor de grațiere care se aflau într-o perioadă de inflație. Din această cauză, jurisprudența abunda în hotărâri judecătorești în legătură cu această materie. În legislația națională, ultimul act de clemență din partea statului este reprezentat de Legea nr. 543/2002 privind grațierea unor pedepse și înlăturarea unor măsuri și sancțiuni ${ }^{5}$. Ulterior acesteia, au mai existat anumite propuneri legislative controversate

\footnotetext{
${ }^{1}$ I. Tanoviceanu, Curs de drept penal, vol. II, Ed. Atelierele Grafice Socec \& Co., Societate anonimă, București, 1912, p. 534.

2 Indulgentia principis era acordată de către romani individual sau colectiv. În Grecia antică, în Atena democrată actele de clemență se acordau prin intermediul adunării poporului. Filosofii stoici au combătut dreptul de grațiere, deoarece acesta „iartă ceea ce trebuie a fi pedepsit, înțeleptul însă nu face nimic care nu trebuie făcut, nici omite ceea ce trebuie făcut". A se vedea I. Tanoviceanu, op. cit., p. 536; V. Dongoroz, Drept penal, Reeditarea ediției din 1939, Editat de Asociația Română de Științe Penale, București, 2000, p. 578; $I$. Mândru, Amnistia și grațierea, Ed. All Educational, București, 1998, p. 60.

${ }^{3}$ C. Beccaria, Despre infracțiuni și pedepse, Editura Științifică, București, 1965, pp. 55-56.

${ }^{4}$ Pentru mai multe detalii cu privire la istoria grațierii, a se vedea I. Tanoviceanu, op. cit., pp. 533 și urm.

${ }^{5}$ Publicată în M. Of. nr. 726 din 4 octombrie 2002, cu modificările și completările ulterioare.
} 
care, în final, nu s-au putut concretiza într-o lege de grațiere ${ }^{6}$.

Pentru a putea avea o imagine cât mai clară a interesului prezentei cercetări, este necesară înfățișarea problemei de drept de care instanțele naționale s-au lovit ulterior intrării în vigoare a Legii nr. 543/2002. În acest sens, jurisprudența noastră s-a confruntat cu o practică neunitară în materia modalității de sancționare a concursului de infracțiuni, în caz de grațiere. Anumite pedepse din concurs fiind grațiate total sau parțial chiar înainte de pronunțarea unei hotărâri definitive de condamnare, instanțele s-au pronunțat în mod diferit cu privire la modalitatea de contopire a pedepselor în cazul acestei pluralități de infracțiuni ${ }^{7}$. Drept urmare, instanța supremă a trebuit să medieze această practică neunitară prin intermediul unei decizii obligatorii a secțiilor unite, și anume prin Decizia RIL nr. $X(10) / 2005^{8}$. În cadrul acesteia, au fost evidențiate principalele trei soluții prezente în practica judiciară până în acel moment ${ }^{9}$. Prima dintre acestea a fost aceea a instanțelor care, în caz de concurs de infracțiuni, pentru care au stabilit numai pedepse cu închisoarea, le-au contopit în conformitate cu art. 34 alin. (1) lit. b) din Codul penal din 1969, în sensul că au aplicat pedeapsa cea mai grea, după care, considerând că pedeapsa rezultantă reflectă ansamblul infracțional, au constatat grațierea acesteia. Alte instanțe, dimpotrivă, după stabilirea pedepselor pentru fiecare infracțiune aflată în concurs, au procedat la contopirea acestora și au dispus să fie executată pedeapsa cea mai grea, cu adăugarea unui eventual spor $^{10}$. Ulterior au dispus descontopirea pedepsei rezultante astfel calculate în pedepsele componente, precum și constatarea grațierii celor pentru care a intervenit această măsură de clemență. Ultima dintre soluții a fost aceea a instanțelor care, stabilind pedepse distincte pentru toate infracțiunile aflate în concurs, au constatat grațierea fiecărei pedepse căreia îi era aplicabilă această măsură, iar în final au contopit numai pedepsele executabile, care nu au făcut obiectul grațierii sau care au fost grațiate parțial.

În urma deliberării, instanța supremă a considerat că ultima dintre aceste soluții se prezintă ca fiind cea corectă. Conform interpretării obligatorii, „în situația în care grațierea intervine înainte de soluționarea definitivă a cauzei, operațiunea de contopire nu poate avea loc decât după constatarea grațierii, totală sau, după caz, parțială, a fiecăreia dintre pedepsele stabilite, pentru infracțiunile aflate în concurs, care sunt vizate prin actul de

\footnotetext{
${ }^{6}$ A se vedea Forumul Judecătorilor din România, Observații referitoare la semnalele vehiculate în spațiul public privind iminenta adoptare a unei O.U.G. privind amnistierea sau grațierea unor pedepse, disponibil pe www.juridice.ro.

${ }^{7}$ Exempli gratia, se presupune că instanța a stabilit două pedepse în cazul unui concurs de infracțiuni, prima de 1 an și a doua de 3 ani. Dacă prima dintre acestea a fost grațiată antecondamnatoriu total sau parțial, se pune întrebarea dacă contopirea va include prima pedeapsă așa cum a fost redusă prin actul de clemență sau așa cum a fost inițial stabilită.

8 î.C.C.J., secțiile unite, Decizia RIL nr. X(10)/2005, publicată în M. Of. nr. 123 din 9 februarie 2006, pronunțată în aplicarea Codului penal anterior.

${ }^{9}$ Trebuie menționat faptul că aceste soluții se grefează pe modalitatea de contopire a pedepselor în cazul concursului de infracțiuni de pe Codul penal din 1969. Cu toate acestea, raționamentul nu este diferit în actuala legislație penală, singura diferență fiind aceea că nu mai există un spor facultativ, ci unul obligatoriu, conform art. 39 C.pen.

${ }^{10}$ Astfel, această soluție respectă cu strictețe prevederile Codului penal din 1969 din materia sancționării concursului de infracțiuni. Potrivit art. 34 din acest cod, "când s-au stabilit numai pedepse cu închisoare, se aplică pedeapsa cea mai grea, care poate fi sporită până la maximul ei special, iar când acest maxim nu este îndestulător, se poate adăuga un spor de până la 5 ani".
} 
clemență. Ca urmare, rezultă că nu pot face obiectul contopirii, conform prevederilor art. 34 din Codul penal (Codul penal din 1969 - n.n.), decât pedepsele executabile, pentru care nu a intervenit grațierea sau care au fost grațiate parțial"11 (s.n.).

Problematică. La o primă vedere, soluția aleasă de către î.C.C.J. în Decizia X(10)/2005 pare a fi cea potrivită și cea mai simplu de aplicat de către instanțele de judecată. Totuși, așa cum vom arăta în cele ce urmează, într-un anumit caz particular această decizie obligatorie poate fi pusă sub semnul întrebării cu privire la legalitatea acesteia și la consecințele juridice produse. Această situație este aceea în care, ulterior aplicării actului de grațiere antecondamnatorie asupra unei pedepse stabilite de către instanță, pedeapsa rezultantă calculată potrivit dispozițiilor din decizia menționată este mai mică sau egală cu 1 an sau este comutată (e.g., din pedeapsa închisorii mai mare de 1 an în cea a amenzii penale). Se poate observa faptul că, anterior actului de clemență, pedeapsa rezultantă putea constitui un eventual prim termen al unei recidive, dacă erau îndeplinite și celelalte condiții ${ }^{12}$. Ulterior grațierii, aceasta poate constitui eventual cel mult un prim termen al pluralității intermediare ${ }^{13}$.

Teza centrală. Articolul urmărește să stabilească dacă grațierea ar putea produce un asemenea efect în materia pluralității de infracțiuni. În cadrul acestuia, interpretarea oferită de instanța supremă va fi corelată cu perspectivele doctrinare și jurisprudențiale în materie, dar și cu actualele dispoziții legale din materia recidivei, concursului de infracțiuni și grațierii.

Având în vedere că ultima lege de grațiere a fost adoptată cu aproximativ 20 de ani în urmă ${ }^{14}$, s-ar putea susține că instituția grațierii a intrat într-o anumită desuetudine. În opinia noastră, subiectul rămâne de actualitate, existând întotdeauna posibilitatea ca legiuitorul să stabilească iertarea de pedeapsă a anumitor persoane care s-ar încadra în condițiile actului respectiv de grațiere. Dovada o fac diferitele dezbateri recente cu privire la adoptarea unui asemenea act normativ ${ }^{15}$. Trecutul a arătat întotdeauna că în perioada de funcționare a unei legi de clemență instanțele judecătorești au simțit o împovărare cu litigii privind acordarea efectelor acestei măsuri. Așadar, ar trebui pusă întrebarea dacă jurisprudența obligatorie a instanței supreme în această materie a rămas de actualitate, având în vedere și intrarea în vigoare, între timp, a Noului Cod penal ${ }^{16}$.

\footnotetext{
${ }^{11} \mathrm{O}$ soluție similară a fost stabilită și de către Plenul Tb. Suprem, decizia de îndrumare nr. 5 din 27 martie 1961, pronunțată în aplicarea Codului penal din 1936, apud I. Nedelcu în Codul penal. Comentariu pe articole, ediția 3 (colectiv), Ed. C.H. Beck, București, 2020, p. 620.

12 Potrivit art. 41 C.pen., „există recidivă când, după rămânerea definitivă a unei hotărâri de condamnare la pedeapsa închisorii mai mare de un an şi până la reabilitare sau împlinirea termenului de reabilitare, condamnatul săvârşeşte din nou o infracţiune cu intenţie sau cu intenţie depăşită, pentru care legea prevede pedeapsa închisorii de un an sau mai mare".

${ }^{13}$ Potrivit art. 44 C.pen., „există pluralitate intermediară de infracţiuni când, după rămânerea definitivă a unei hotărâri de condamnare şi până la data la care pedeapsa este executată sau considerată ca executată, condamnatul săvârşeşte din nou o infracţiune şi nu sunt întrunite condiţiile prevăzute de lege pentru starea de recidivă" (s.n.).

${ }^{14}$ Legea nr. 543/2002 privind grațierea unor pedepse și înlăturarea unor măsuri și sancțiuni, precitată.

${ }^{15}$ Pentru detalii, a se vedea M.A. Hotca, Despre grațiere, legalitate, umanism și proporționalitate, disponibil pe www.juridice.ro.

${ }^{16}$ Adoptat prin Legea nr. 286/2009, publicată în M. Of. nr. 510 din 24 iulie 2009, cu modificările și completările ulterioare.
} 
Structură. în sensul arătat, într-o primă parte vor fi evidențiate aspectele teoretice relevante studiului, alături de prezentarea principiului individualizării depline a pedepsei (I și II). Acestea vor fi realizate pentru a putea analiza modificarea mecanismului de sancționare a concursului de infracțiuni prin intermediul grațierii antecondamnatorii (III). Ulterior, vom dezvolta, argumenta și compara o propunere pentru soluționarea problemei de drept înfățișate (IV).

\section{CONSIDERAṬII TEORETICE RELEVANTE ALE INSTITUȚIEI GRAṬIERII}

\section{Definiție și tipologie}

Grațierea reprezintă, conform art. 1 din Legea nr. 546/2002 privind grațierea și procedura acordării grațierii ${ }^{17}$, "măsura de clemență ce constă în înlăturarea, în total sau în parte, a executării pedepsei aplicate de instanță ori în comutarea acesteia în una mai ușoară". Aceasta reprezintă o măsură de excepție acordată de către puterea publică, având ca temei diverse motive de ordin social sau moral. Beneficiile acestei instituții constau în iertarea executării de către condamnat a pedepsei. Din acest motiv, doctrina de drept penal a încadrat această instituție de drept în interiorul cauzelor care modifică sau înlătură executarea pedepsei ${ }^{18}$, alături de instituția prescripției executării pedepsei. În acest sens, în Noul Cod penal grațierea se regăsește în dispozițiile Titlului VIII din cadrul Părții generale, intitulat "Cauzele care înlătură sau modifică executarea pedepsei”"19.

Pentru a putea contura obiectul prezentei cercetări, este necesară delimitarea diferitelor clasificări apărute în legislație și în literatura de specialitate 20 . Încă din definiția legală prezentă în Legea nr. 546/2002 (denumită în continuare și Legea grațierii) se poate observa că grațierea poate interveni în două modalități diferite. Prima dintre acestea este cea prin intermediul căreia pedeapsa stabilită de către instanța de judecată se stinge total sau parțial ${ }^{21}$. A doua este reprezentată de comutarea pedepsei sau, mai bine zis, de înlocuirea pedepsei stabilite cu o altă pedeapsă de altă natură, mai ușoară22.

Totodată, conform art. 2 din legea menționată, aceasta poate fi acordată individual (in personam) de către Președintele României prin decret, potrivit dispozițiilor art. 94 lit. d) din Constituția României republicată ${ }^{23}$, sau colectiv (in rem) ${ }^{24}$, de către Parlament prin lege organică, conform prevederilor art. 73 alin. (3) lit. i) din Constituția României.

\footnotetext{
17 Publicată în M. Of. nr. 515 din 14 august 2013, cu modificările și completările ulterioare.

${ }^{18}$ A se vedea C. Mitrache, C. Mitrache, Drept penal român, ediția a 3-a, Ed. Universul Juridic, București, 2019, pp. 528-536; L.V. Lefterache, Drept penal. Partea generală. Curs pentru studenții anului II, ediția a 2-a, Ed. Hamangiu, București, 2018, pp. 471-474; V. Dongoroz, op. cit., pp. 577-579; V. Pașca, Drept penal. Partea generală, ediția a 4-a, Ed. Universul Juridic, București, 2015, pp. 590-593.

19 Art. 160 C.pen. reia în linii mari definiția legală regăsită în Legea nr. 546/2002. Potrivit acestui articol, "grațierea are ca efect înlăturarea, în totul sau în parte, a executării pedepsei ori comutarea acesteia în alta mai ușoară".

${ }^{20}$ Pentru o analiză, pe larg, a clasificărilor din materia grațierii, a se vedea M. Udroiu, Sinteze de Drept penal. Partea generală, Ed. C.H. Beck, București, 2020, pp. 943-946.

21 Potrivit art. 16 alin. (1) din Legea nr. 546/2002, „grațierea este totală atunci când privește pedeapsa principală în integralitatea ei”, iar, potrivit alin. (2) al aceluiași articol, „grațierea parțială poate privi o parte determinată din pedeapsă, o parte calculată prin raportare la pedeapsa în întregul ei, precum și restul pedepsei rămase de executat".

${ }^{22}$ R. Moroșanu, Aspecte controversate în materia grațierii, Ed. Hamangiu, București, 2007, p. 5.

${ }^{23}$ Adoptată prin Legea nr. 429/2003, publicată în M. Of. nr. 758 din 29 octombrie 2003.
} 
Art. 3 din Legea grațierii precizează faptul că grațierea individuală se acordă la cerere sau din oficiu, „numai după rămânerea definitivă a hotărârii de condamnare”. Interpretând per a contrario textul de lege, se poate trage concluzia că grațierea colectivă poate interveni atât anterior, cât și posterior unei hotărâri definitive. Așadar, prin aceasta se instituie o altă tipologie a instituției grațierii, și anume cea care conține grațierea postcondamnatorie și cea antecondamnatorie. Grațierea postcondamnatorie, denumită și grațiere propriu-zisă, intervine ulterior pronunțării unei hotărâri definitive, iar cea antecondamnatorie, denumită și grațiere anticipată, intervine anterior unei asemenea hotărâri ${ }^{25}$.

Fiind un atribut exclusiv și discreționar al șefului de stat, grațierea individuală se acordă întotdeauna necondiționat. Pe de altă parte, grațierea colectivă, fiind un apanaj legislativ al Parlamentului care se acordă tuturor persoanelor aflate în aceeași situație juridică, poate interveni atât sub formă necondiționată, cât și sub anumite condiții strict delimitate în actul normativ respectiv ${ }^{26}$. De regulă, aceste condiții au legătură cu infracțiunile săvârșite, cu pedeapsa prevăzută de lege sau cu persoana condamnatului ${ }^{27}$.

Concluzionând sub acest aspect, având în vedere și dispozițiile Deciziei RIL $X(10) / 2005$ menționate mai sus, obiectul de studiu al prezentului demers se va concentra pe analizarea mecanismului specific de operare și al efectelor juridice produse în cadrul grațierii colective intervenite antecondamnatoriu. Totodată, vor fi analizate și comparate anumite situații particulare care se pot ivi în practică în legătură cu celelalte modalități prezentate ale grațierii ${ }^{28}$.

\section{Efectele grațierii antecondamnatorii în materia pluralității de infracțiuni}

Așa cum excelent s-a subliniat în doctrină, „grațierea înlătură executarea pedepsei, ea nu înlătură condamnarea și consecințele condamnării, astfel că o pedeapsă grațiată are aceleași efecte ca o pedeapsă executată"29. Așadar, grațierea face ca pedeapsa aplicată de către instanță condamnatului să apară ca fiind executată. În acest sens, se poate deduce în mod evident că instituția grațierii are ca obiect pedeapsa și nu infracțiunea sau răspunderea penală ${ }^{30}$.

După cum am precizat și mai sus, cea mai importantă clasificare a grațierii pentru lucrarea de față este cea care se face în funcție de momentul în care aceasta intervine. În cadrul Legii grațierii, în art. 13 alin. (2) se precizează faptul că „atunci când legea de grațiere intră în vigoare înaintea rămânerii definitive a hotărârii de condamnare (grațiere antecondamnatorie - n.n.), grațierea își produce efectele numai de la data rămânerii definitive a hotărârii". În cazul grațierii postcondamnatorii, efectele se produc de la data intrării în vigoare a actului de clemență ${ }^{31}$. Așa cum se poate vedea, distincția dintre cele două tipuri de grațiere are loc numai la nivelul momentului de la care efectele se produc.

\footnotetext{
24 Potrivit art. 12 din Legea nr. 546/2002, „grațierea colectivă se acordă unui număr de persoane pentru condamnări determinate prin cuantumul pedepselor sau prin infracțiunile pentru care au fost pronunțate".

${ }^{25}$ R. Moroșanu, op. cit., pp. 4-6.

${ }^{26}$ Dispoziție prevăzută în mod expres în art. 17 din Legea nr. 546/2002.

${ }^{27}$ A se vedea, pentru diverse exemple din legi sau decrete de grațiere, I. Nedelcu în Codul penal. Comentariu pe articole, ediția 3 (colectiv), Ed. C.H. Beck, București, 2020, pp. 619-620.

${ }^{28}$ Infra, pp. 17-18.

${ }^{29}$ C. Mitrache, C. Mitrache, op. cit., p. 532.

${ }^{30}$ M. Udroiu, op. cit., p. 942, nota de subsol nr. 1.

${ }^{31}$ A se vedea V. Pașca, op. cit., p. 593.
} 
Dacă legiuitorul ar fi stabilit că grațierea care intervine în cursul procesului penal își va produce efectele de la data actului de clemență, aceasta ar fi înlăturat cu totul procesul de individualizare judiciară și de stabilire a pedepsei. În această situație nu ar mai fi existat vreun raționament pentru acestea. Acest fapt conduce la concluzia că, de lege lata, s-a dorit ca grațierea antecondamnatorie să-și producă efectele ca și cum ar fi intervenit postcondamnatoriu ${ }^{32}$.

În cazul unor infracțiuni aflate în concurs, grațierea colectivă produce efecte asupra pedepselor aplicate pentru fiecare dintre acestea, și nu asupra pedepsei rezultante ${ }^{33}$. În acest caz, conform art. 14 alin. (2) din Legea grațierii, „dacă pentru unele dintre aceste pedepse este incidentă grațierea, ele vor fi descontopite, iar dacă a rămas o singură pedeapsă din pedeapsa rezultantă, care nu este grațiată, va fi înlăturat și sporul eventual aplicat ${ }^{\prime 34}$. Prima facie, s-ar părea că acest text de lege se aplică grațierii colective, fără a se face vreo distincție cu privire la delimitarea dintre grațierea antecondamnatorie și cea postcondamnatorie. Totuși, folosind metoda de interpretare logică a textului citat, se poate deduce că legiuitorul a avut în vedere doar situația unei grațieri colective, care intervine ulterior pronunțării unei hotărâri definitive de condamnare. Acest raționament se bazează pe faptul că se menționează în mod expres că pedeapsa se descontopește. Prin urmare, există deja o pedeapsă rezultantă aplicată de către instanța de judecată, urmând ca o parte din aceasta să fie considerată executată ${ }^{35}$.

\section{PRINCIPIUL INDIVIDUALIZĂRII DEPLINE A PEDEPSEI ȘI IMPLICAṬIILE ACESTUIA ÎN MATERIA GRAṬIERII}

Doctrina care s-a aplecat în detaliu asupra problemelor pe care le poate genera grațierea colectivă antecondamnatorie a analizat și situația în care instanțele de judecată sunt confruntate cu infracțiuni aflate în concurs, dintre care unele sau chiar toate intră sub incidența actului de clemență 36 .

În cazul acestui tip de pluralitate de infracțiuni, pentru a se pronunța asupra pedepsei pe care o va avea de executat inculpatul, instanța trebuie să parcurgă două etape. Prima dintre acestea este reprezentată de stabilirea pedepselor pentru fiecare infracțiune în parte. A doua etapă este reprezentată de calcularea pedepsei rezultante, contopind potrivit dispozițiilor legale pedepsele stabilite anterior ${ }^{37}$. Întrebarea care se pune este dacă instanța

\footnotetext{
32 Pentru un exemplu practic care considerăm că justifică această ipoteză, a se vedea C.Ap. București, Secția Penală, decizia penală nr. 529/2017 (www.rolii.ro). Curtea a menționat că, fiind vorba de o grațiere colectivă antecondamnatorie, aceasta „ar fi trebuit constatată chiar de instanța învestită cu judecarea infracțiunilor respective, după ce în prealabil ar fi dispus condamnarea" (s.n.).

${ }^{33}$ Art. 14 alin. (1) din Legea nr. 546/2002.

34 Trebuie evidențiată neconcordanța acestei dispoziții cu actualele reguli din materia contopirii pedepselor în cazul unui concurs de infracțiuni. Astfel, potrivit art. 39 C.pen., în caz de concurs de infracțiuni, "când s-au stabilit numai pedepse cu închisoare, se aplică pedeapsa cea mai grea, la care se adaugă un spor (obligatoriu n.n.) de o treime din totalul celorlalte pedepse stabilite".

${ }^{35} \mathrm{Cu}$ toate acestea, în cadrul practicii neunitare reliefate în Decizia X(10)/2005 a î.C.C.J., unele instanțe au aplicat această modalitate de sancționare a concursului și în cazul grațierii antecondamnatorii. Astfel, acestea au contopit pedepsele, ulterior descontopindu-le pentru a calcula o nouă pedeapsă rezultantă care să conțină pedepsele așa cum au fost grațiate.

${ }^{36}$ I. Mândru, op. cit., pp. 400-403.

37 Pentru o analiză detaliată a sancționării concursului de infracțiuni, a se vedea F. Streteanu, D. Nițu, Drept penal. Partea generală, vol. II, Ed. Universul Juridic, București, 2018, pp. 119-123.
} 
trebuie să contopească pedepsele stabilite fără a lua în calcul actul de grațiere anticipată sau dacă, dimpotrivă, trebuie să le contopească ținând cont, în parte, de cum au fost micșorate sau comutate în urma măsurii de clemență. După cum am putut vedea, această ultimă variantă este considerată corectă și de jurisprudența î.C.C.J. din Decizia RIL $X(10) / 2005$.

Astfel, s-au conturat două opinii separate, ambele având susțineri atât din partea jurisprudenței, cât și din partea autorilor de drept penal. Cele două soluții sunt diferite atât din punct de vedere procedural, cât și din punct de vedere al consecințelor juridice produse. Pentru prima dintre aceste variante un autor introduce un nou concept, și anume „imperativul individualizării depline a pedepsei”38. Potrivit acestui principiu, grațierea nu poate interveni în procesul de individualizare judiciară a pedepsei. Grațierea antecondamnatorie este o măsură de modificare a pedepsei efectiv aplicate inculpatului în urma deliberării instanței. Grațierea nu poate întrerupe atributul exclusiv al instanței de adaptare a sancțiunilor penale, instituit de alt principiu fundamental dreptului penal, și anume principiul individualizării pedepselor ${ }^{39}$.

În sensul arătat, argumentele prezentate în favoarea acestui deziderat sunt numeroase, având ca punct de plecare efectele legale pe care grațierea le poate produce, înfățișate mai sus. Profesorul lancu Mândru aduce ca prim argument în susținerea acestei ipoteze faptul că „împrejurarea că pedeapsa nu va fi executată nu poate constitui un element de natură a influența individualizarea pedepsei. Aceasta ar însemna adăugarea la lege a unei alte condiții decât cele la care se referă art. 72 C.pen. (actualul art. 74 din Noul Cod penal, privind criteriile generale de individualizare - n.n.), ceea ce ar apărea ca inadmisibil”40. Un al doilea argument în acest sens este acela că, „prin însăși natura sa juridică, grațierea nu poate premerge individualizării pedepsei, ci urmează, în mod necesar, acesteia". Un al treilea argument susținut este că „înfăptuirea unei bune judecăți presupune, ori de câte ori este posibil, ca pedeapsa să fie aplicată de către completul de judecată în fața căruia s-a desfășurat procesul penal. Acesta are la îndemână date și elemente pe care numai cu greu le poate strânge instanța chemată a hotărî asupra contopirii pedepselor, ca urmare a săvârșirii unei infracțiuni înăuntrul termenului de încercare" ${ }^{41}$. Ca o concluzie, „potrivit unui vechi principiu, judecătorii vor judeca faptele fără a ține seama de grațiere, ca și cum actul de clemență nu ar exista. Individualizarea pedepsei, pe de o parte, și reducerile, comutările și remiterile cuvenite, pe de alta, constituie operații distincte" ${ }^{\prime \prime 2}$.

Un argument în sensul respingerii unui asemenea imperativ pe care instanța de judecată ar trebui să-I respecte în cadrul individualizării, stabilirii și aplicării pedepselor a fost susținut de profesorul Costică Bulai. Acesta considera că nu este utilă contopirea pedepselor grațiate anticipat, deoarece revocarea grațierii condiționate reprezintă un

\footnotetext{
38 I. Mândru, op. cit., p. 400.

39 Potrivit acestui principiu, sancțiunile penale trebuie să fie adaptate astfel încât să caracterizeze gravitatea faptei și periculozitatea făptuitorului. A se vedea, în acest sens, L.V. Lefterache, op. cit., p. 44; F. Streteanu, D. Nițu, Drept penal. Partea generală, vol. I, Ed. Universul Juridic, 2014, București, pp. 65-71.

${ }^{40}$ A se vedea și Tb. Neamț, decizia penală nr. 296/1982, apud I. Mândru, op. cit., p. 401.

${ }^{41}$ I. Mândru, op. cit., p. 400. Autorul mai aduce în discuție și alte argumente, cum este acela că „grațierea nu înlătură concursul de infracțiuni și pericolul social rezultat din acesta” sau acela că „între regula aplicării actului de grațiere asupra pedepselor stabilite și continuarea operației de individualizare, în scopul cunoașterii pedepsei unice pentru tot concursul de infracțiuni, nu există nicio incompatibilitate".

${ }^{42}$ Idem, p. 401. Pentru o opinie similară, a se vedea și I. Tanoviceanu, op. cit., pp. 546-547.
} 
eveniment viitor și excepțional ${ }^{43}$. Un alt argument de respingere a acestui principiu ar fi reprezentat de dispozițiile Legii grațierii cu privire la modalitatea de contopire a pedepselor aflate în cadrul unei pluralități de infracțiuni, în caz de grațiere colectivă. Așa cum am prezentat mai sus, respectivul text de lege se aplică doar în cazul grațierii postcondamnatorii.

În cele ce urmează, vor fi aduse în discuție anumite aspecte în legătură cu actualele opinii doctrinare și jurisprudențiale cu privire la condițiile de sancționare a concursului de infracțiuni. Acestea vor face legătura atât cu principiul mai sus menționat, dar și cu posibila soluție de rezolvare a problemei de drept și cu argumentele pe care le vom prezenta.

\section{PEDEAPSĂ EXECUTABILĂ - CONDITIIE A CONCURSULUI DE INFRACTIIUNI?}

În ceea ce privește aspectele esențiale pe care î.C.C.J. le-a statuat în Decizia $X(10) / 2005$, s-a evidențiat faptul că pot face obiectul contopirii, în cazul unui concurs de infracțiuni, doar pedepsele executabile, fără a lua în calcul și cele care au fost grațiate anticipat, total sau parțial. În cazul acesta, după cum am subliniat anterior, pedeapsa rezultantă se va micșora, în mod firesc, față de situația în care grațierea nu ar fi intervenit ${ }^{44}$. Acest lucru va conduce la anumite consecințe, inevitabile de astfel, în legătură cu îndeplinirea condițiilor privind primul termen al unei eventuale recidive.

După cum se poate observa, instanța supremă a dedus existența unei noi condiții în materia concursului de infracțiuni. Trebuie reținut încă de la început că aceasta nu se află în strictă legătură cu existența efectivă a pluralității de infracțiuni, ci, mai degrabă, cu modalitatea de sancționare a acesteia. Cu toate acestea, modul de sancționare a concursului reprezintă cel mai important element al acestei instituții de drept ${ }^{45}$. Având în vedere că, potrivit art. 39 alin. (1) C.pen., instanța va stabili pedeapsa pentru fiecare dintre infracțiuni și ulterior va calcula pedeapsa rezultantă, cea din urmă se va comporta întocmai ca o pedeapsă obișnuită ${ }^{46}$. Drept urmare, toate condițiile privind pedeapsa aplicată din cadrul recidivei, pluralității intermediare, renunțării sau amânării aplicării pedepsei, suspendării sub supraveghere, liberării condiționate și reabilitării se vor grefa pe rezultanta acestei pluralități de infracțiuni calculată de către instanță. Așadar, a crea o condiție cu asemenea efecte juridice în majoritatea instituțiilor de drept penal va conduce, în mod firesc, la anumite semne de întrebare privind temeinicia și legalitatea acesteia.

\footnotetext{
${ }^{43}$ C. Bulai în Practica judiciară penală, vol. I, Ed. Academiei Române R. S. România, București, 1988, pp. 140141, apud I. Mândru, op. cit., p. 401.

${ }_{44}^{4}$ Pentru un exemplu practic din jurisprudență cu privire la aplicarea Deciziei X(10)/2005 a Î.C.C.J., a se vedea C.Ap. București, Secția Penală, decizia penală nr. 184/2017 (www.rolii.ro). Fiind vorba de o contestație la executare, instanța a constatat faptul că „faptele pentru care inculpatul a fost judecat și condamnat în cele două cauze erau concurente, iar regimul sancționator nu a putut fi aplicat în contextul în care una dintre pedepse a fost grațiată. Curtea are în vedere Decizia X/2005 prin care î.C.C.J. a statuat că în caz de concurs de infracțiuni, dintre care pentru unele s-au stabilit pedepse ce au făcut obiectul grațierii, dispozițiile referitoare la contopire se aplică numai cu privire la pedepsele executabile ce nu au făcut obiectul grațierii sau care au fost grațiate parțial”.

${ }^{45}$ F. Streteanu, D. Nițu, op. cit., vol. II, p. 95.

${ }^{46}$ Conform literaturii de specialitate, „sancțiunile ce au fost contopite își pierd individualitatea, pedeapsa rezultantă fiind stabilită pentru o pluralitate de fapte privite ca un întreg". A se vedea, pentru mai multe detalii, A. Cocaină, Recidiva în dreptul penal român, Ed. Lumina Lex, București, 1995, p. 62.
} 
În doctrina de drept penal, printre condițiile concursului de infracțiuni, majoritatea autorilor o adaugă și pe aceea ca cel puțin două dintre infracțiuni să poată atrage o condamnare sau să poată fi judecate ${ }^{47}$. Această condiție semnifică faptul că, pentru cel puțin două dintre infracțiuni, este necesar să nu fi intervenit anumite impedimente care să înlăture posibilitatea instanței de a stabili o pedeapsă. Conform doctrinei ${ }^{48}$, acestea sunt reprezentate de cauzele care înlătură răspunderea penală ${ }^{49}$, de lipsa autorizării sau sesizării organului competent și de cauzele de nepedepsire ${ }^{50}$. Așadar, grațierea nu face parte din niciuna dintre aceste piedici la stabilirea unei pedepse.

Potrivit celor arătate, se poate deduce că între executabilitatea pedepsei și posibilitatea instanței de a aplica o pedeapsă există un raport de tipul întreg-parte. În acest sens, se poate afirma că pedepsele care nu pot fi executate includ și acele infracțiuni cărora instanța nu le poate aplica o pedeapsă concretă. În sens contrar, conform Deciziei RIL X(10)/2005, ar părea că raportul dintre acestea se inversează. Așadar, condiția ca instanța să poată aplica o pedeapsă ar conține și alte impedimente pe lângă cele prezentate în doctrina actuală. în acest fel, am putea adăuga în această categorie și cauzele care înlătură sau modifică executarea pedepsei, din care fac parte grațierea și prescripția executării pedepsei ${ }^{51}$.

După părerea noastră, efectele evidențiate în prima parte a lucrării de față cu privire la grațiere contrazic o asemenea condiție pentru sancționarea concursului de infracțiuni. De asemenea, principiul individualizării depline a pedepsei și argumentele aduse în discuție în favoarea acestuia nu susțin considerentele din Decizia RIL X(10)/2005 a Î.C.C.J. Ba mai mult, conform opiniei profesorului Streteanu, în materia sancționării concursului de infracțiuni, „chiar și în ipoteza grațierii colective totale este de dorit contopirea pedepselor stabilite"52. În sensul arătat se aduc două argumente. În primul rând, „în funcție de pedeapsa rezultantă, fie ea și grațiată necondiționat, se poate determina în viitor vocația infractorului de a beneficia de anumite modalități de individualizare”. În al doilea rând, „dacă pedepsele sunt grațiate condiționat, este normal ca făptuitorul să cunoască din hotărâre care este pedeapsa pe care o va avea de executat în caz de revocare a grațierii, ceea ce poate contribui în mod eficient la prevenția specială"53 (s.n.). Acest din urmă principiu derivă din cel al prevenției generale ${ }^{54}$. Principiul prevenției speciale, denumit în doctrină și „scopul direct al pedepsei”55,

\footnotetext{
47 În acest sens, a se vedea V. Dongoroz, op. cit., p. 272; L.V. Lefterache, op. cit., p. 368; C. Mitrache, C. Mitrache, op. cit., p. 332. Alți autori preferă să denumească această condiție „posibilitatea de aplicare a unei pedepse". A se vedea F. Streteanu, D. Nițu, op. cit., vol. II, p. 94; V. Pașca, op. cit., p. 327.

${ }^{48}$ F. Streteanu, D. Nițu, op. cit., vol. II, pp. 95-96, pct. 654.

${ }^{49}$ Conform dispozițiilor Titlului VII al Părții generale din Noul Cod penal, cauzele care înlătură răspunderea penală sunt amnistia, prescripția răspunderii penale, lipsa și retragerea plângerii prealabile și împăcarea.

${ }^{50}$ Cauzele de nepedepsire reprezintă acele soluții de politică penală care au ca scop apărarea de pedeapsă a celui care a comis o infracțiune, regăsindu-se de cele mai multe ori în textele de lege din Partea specială a Codului penal sau în legi speciale. De obicei, acestea au legătură cu rudenia sau atitudinea avută de către inculpat în timpul săvârșirii faptei. Pentru mai multe detalii, a se vedea L.V. Lefterache, op. cit., p. 186.

${ }^{51}$ Trebuie subliniat faptul că prescripția executării pedepsei va putea interveni întotdeauna doar după pronunțarea hotărârii definitive de condamnare prin care a fost calculată pedeapsa rezultantă. Pentru mai multe detalii, a se vedea C. Mitrache, C. Mitrache, op. cit., p. 536.

${ }^{52}$ F. Streteanu, D. Nițu, op. cit., vol. II, p. 122.

${ }^{53}$ Ibidem.

${ }^{54}$ Potrivit principiului prevenției generale, pedeapsa stabilită de lege conduce la reținerea de a comite infracțiuni și la atenționarea celor care doresc să încalce legea penală cu privire la consecințele juridice care se pot ivi.
} 
se referă la persoana care a comis o infracțiune și căreia i-a fost aplicată o pedeapsă. Drept urmare, aceasta trebuie să sufere consecințele faptei, reflectând astfel la conduita pe care o va avea în viitor ${ }^{56}$. Din punct de vedere psihologic, această reflectare are ca sursă nu numai oprobriul public la care condamnatul este supus ulterior condamnării definitive. Acesta se va raporta la viitoarea conduită mai ales în funcție de pedeapsa globală aplicată de către instanță, cu toate consecințele juridice care decurg din aceasta. Faptul că între timp intervine un act de clemență din partea statului nu ar trebui să stopeze buna funcționare a justiției penale și a autorității de lucru judecat. Prin urmare, acest principiu fundamental al dreptului penal și dreptului execuțional penal ${ }^{57}$ nu se află în concordanță cu posibilitatea instanței de judecată de a micșora pedeapsa pe care o „merită” 58 inculpatul pentru ansamblul infracțional. Chiar dacă, în cadrul judecății, instanța este obligată să constate grațierea anticipată, aceasta este obligată, de asemenea, să respecte condițiile legale și principiile care definesc dreptul penal.

Una dintre problemele majore în legătură cu acest subiect este reprezentată de practica anumitor instanțe de judecată. După cum vom arăta, unele dintre acestea au aplicat, în mod ad litteram, considerentele Deciziei $X(10) / 2005$, fără a realiza o analiză asupra condițiilor instituțiilor de drept în cauză și a consecințelor juridice. Există și alte soluții posibile de rezolvare a acestei probleme de drept, care să respecte atât principiile statornicite de întreaga doctrină și jurisprudență în materie penală, cât și condițiile legale din materia concursului de infracțiuni și ale recidivei.

În continuare, va fi analizată varianta pe care o considerăm oportună pentru soluționarea problemei puse în discuție, coroborând analiza cu condițiile și efectele recidivei, cu cele reliefate mai sus și cu alte aspecte relevante studiului.

\section{EVIDENTTIEREA ȘI CONTOPIREA PEDEPSEI REZULTANTE ULTERIOR ACTULUI DE GRAṬIERE ANTICIPATĂ}

\section{Aspecte introductive}

Soluțiile practicii judiciare anterioare deciziei obligatorii a î.C.C.J. s-au axat, în principal, pe trei modalități diferite de evidențiere a pedepsei rezultante în cadrul hotărârii definitive de condamnare ${ }^{59}$. Problema care se pune este că, din punct de vedere legal, unele dintre aceste modalități depășesc sfera consecințelor juridice pe care le poate produce un act de clemență. În principiu, după cum am arătat, de lege lata, instituția grațierii face parte din cauzele care înlătură executarea pedepsei. Soluția pe care instanța supremă a considerat-o corectă ar părea că infirmă această încadrare juridică. Avem în vedere faptul că, în această situație, grațierea antecondamnatorie ar înlătura nu numai executarea

\footnotetext{
${ }^{55}$ F. Streteanu, D. Nițu, op. cit., vol. II, p. 284.

56 Acest principiu are în componentele sale mai multe funcții, printre care se numără funcția retributivă, funcția de intimidare și funcția de reeducare. Pentru mai multe detalii, a se vedea Idem, p. 283.

57 Pentru opinia legiuitorului cu privire la rolul, scopul și funcțiile pedepsei, a se vedea art. 3 din Legea nr. 254/2013 privind executarea pedepselor şi a măsurilor privative de libertate dispuse de organele judiciare în cursul procesului penal, publicată în M. Of. nr. 514 din 14 august 2013, cu modificările și completările ulterioare.

58 Seneca definește foarte precis grațierea ca fiind remiterea pedepsei meritate. A se vedea, S. Braund (editor), Seneca: De clementia, Ed. Oxford University Press, 2009.

${ }^{59}$ A se vedea supra, p. 3.
} 
pedepsei, dar și posibilitatea încadrării în condițiile unei eventuale stări de recidivă. Așadar, instituția grațierii ar face parte automat din cauzele care înlătură consecințele condamnării ${ }^{60}$.

În acest context, vom analiza o jurisprudență a instanțelor naționale care sperăm să confere o imagine mai clară a consecințelor juridice produse în materia grațierii și a recidivei de soluția considerată oportună de către î.C.C.J. în Decizia X(10)/2005. Ulterior, vom aduce în discuție o posibilă soluție de rezolvare a acestei probleme de drept care să respecte atât condițiile legale, cât și principiul prevenției speciale și cel al individualizării depline a pedepsei. Tot în acest sens, vor fi realizate și anumite comparații cu privire la alte situații particulare care s-au ivit sau care se pot ivi în practică.

\section{Practica judiciară ulterioară Deciziei X(10)/2005 a î.C.C.J.}

Ulterior pronunțării de către instanța supremă a Deciziei RIL X(10)/2005, instanțele naționale s-au confruntat în numeroase cazuri cu aceeași problemă de drept. De această dată, acestea erau obligate să respecte considerentele recursului în interesul legii și de a aplica, în mod automat, modalitatea de contopire a pedepselor potrivit acestuia. Astfel, instanțele au contopit pedepsele stabilite pentru infracțiunile din concurs, aplicând asupra fiecăreia, în prealabil, actul de grațiere care micșora durata acestora. În acest mod, grațierea intervenea de fiecare dată în procesul de individualizare judiciară a pedepselor, anterior contopirii lor.

Un exemplu din jurisprudență ar putea fi elocvent pentru prezentarea efectelor nefaste pe care le poate produce această modalitate de stabilire și de contopire a pedepselor aflate în concurs. În acest sens, este oportună analiza pe care o realizează Curtea de Apel București în cadrul unei decizii penale ce are ca obiect o contestație la executare ${ }^{61}$. Situația premisă este aceea a două infracțiuni aflate în concurs real (judecate în mod separat) ${ }^{62}$ și a unei infracțiuni care a fost săvârșită ulterior pronunțării unei hotărâri definitive de condamnare, care se află în stare de recidivă postcondamnatorie față de celelalte. Pentru prima dintre infracțiunile aflate în concurs, instanța care a judecat-o a stabilit pentru aceasta o pedeapsă cu închisoarea de 3 ani. Pentru cea de-a doua infracțiune, a fost stabilită o pedeapsă cu închisoarea de 2 ani. Având în vedere că prima dintre aceste hotărâri de condamnare "a fost pronunțată după intrarea în vigoare a unui act de clemență, respectiv Legea nr. 543/2002, pedeapsa a fost grațiată, astfel încât nu putea fi contopită cu alte pedepse, nefiind o pedeapsă executabilă". Așadar, instanța care trebuia să contopească ambele pedepse din concurs I-a condamnat pe inculpat doar la executarea pedepsei de 2 ani închisoare (reprezentând pedeapsa pentru a doua infracțiune din concurs) pentru ansamblul infracțional. Curtea de Apel a apreciat că „instanța a procedat în mod corect la constatarea ca fiind grațiată a pedepsei fără a o contopi cu celelalte pedepse, deoarece o pedeapsă grațiată nu poate fi contopită cu alte pedepse care sunt executabile". În acest sens, se

\footnotetext{
${ }^{60}$ Potrivit Titlului IX al Părții generale din Noul Cod penal, cauzele care înlătură consecințele condamnării sunt reabilitarea de drept și cea judecătorească.

${ }^{61}$ A se vedea C.Ap. București, Secția Penală, decizia penală nr. 1303/R/2009, pronunțată în aplicarea Codului penal anterior (www.rolii.ro).

62 În acest caz, se aplică dispozițiile art. 36 din Codul penal din 1969 (actualul art. 40 din Noul Cod penal), privitoare la situația în care există mai multe hotărâri definitive de condamnare pentru infracțiuni aflate în concurs.
} 
menționează ca temei legal dispozițiile Deciziei RIL nr. X(10)/2005. Așadar, se poate observa că, dacă actul de grațiere antecondamnatorie nu ar fi intervenit, pedeapsa rezultantă ar fi fost, în mod firesc, mai mare.

Din perspectiva infracțiunii care constituia termenul al doilea al recidivei, instanța de judecată a stabilit o pedeapsă cu închisoarea de 2 ani și jumătate. Interesant este de observat faptul că, potrivit Curții de Apel București, primul termen al acestei recidive era reprezentat nu de ambele infracțiuni aflate în concurs, ci doar de cea care nu a fost grațiată. În acest sens, se precizează că: „din această perspectivă, condamnarea aplicată prin sentința penală X (infracțiunea din concurs negrațiată - n.n.) constituie primul termen al stării de recidivă mare postcondamnatorie față de pedeapsa aplicată prin sentința penală Y". Astfel, „petentul se află în situația în care, după rămânerea definitivă a unei hotărâri de condamnare la pedeapsa închisorii mai mare de 6 luni a săvârșit din nou o infracțiune cu intenție, în timpul executării pedepsei, iar pedeapsa prevăzută de lege pentru a doua infracțiune este mai mare de $1 a^{\prime \prime 63}$. Prin urmare, se pare că prin intermediul grațierii antecondamnatorii prima infracțiune a fost ștearsă cu totul din antecedentele penale ale respectivului inculpat.

Având în vedere că în speța prezentată chiar și după intervenirea grațierii totale a unei pedepse din concurs au fost îndeplinite condițiile termenului I al recidivei, se poate afirma că Decizia RIL X(10)/2005 nu a afectat foarte mult soluția instanței. Cu toate acestea, este interesant de văzut ce s-ar fi întâmplat dacă pedeapsa negrațiată nu s-ar fi încadrat în condițiile recidivei de pe Codul penal din 1969. Conform interpretării din decizia menționată a instanței supreme și a unei alte jurisprudențe naționale ${ }^{64}$, se pare că inculpatul nu s-ar mai fi aflat în stare de recidivă, ci în stare de pluralitate intermediară. Acest fapt conduce, în mod evident, la situația în care acestuia i s-ar fi aplicat un tratament sancționator mai lejer ${ }^{65}$ doar pentru motivul că, înainte de pronunțarea condamnării definitive, a intervenit o cauză care a înlăturat executarea pedepsei.

$\mathrm{Ne}$ punem astfel întrebarea dacă grațierea, pe lângă iertarea executării unei pedepse, poate conferi beneficiarului și iertarea unei eventuale stări de recidivă?

\section{Pedeapsa condamnatorie și pedeapsa executorie}

Considerăm că pentru rezolvarea problemei de drept aduse în discuție, se impune ca soluția propusă să respecte toate considerentele prezentate anterior în lucrarea de față. Practic, este necesar ca modalitatea de evidențiere a pedepsei rezultante și de contopire a acesteia să se „muleze” într-un mod natural pe efectele legale produse de grațiere și pe condițiile legale impuse de dispozițiile Noului Cod penal în materia recidivei. De asemenea,

\footnotetext{
63 Trebuie subliniat faptul că aceste condiții ale recidivei sunt cele regăsite în art. 37 din Codul penal din 1969.

${ }^{64}$ A se vedea Tb. Suprem, c7, decizia penală nr. 41/1986, apud A. Cocaină, op. cit., p. 59. Cu privire la aceasta, autorul citat menționează că „în practica judiciară s-a decis că pedeapsa rezultantă mai mare de 6 luni, ca urmare a grațierii, nu mai poate constitui prim termen al recidivei, în cazul comiterii unei noi infracțiuni, întrucât aceasta nu mai este în ființă. Ca urmare a descontopirii, pedepsele își dobândesc individualitatea și se constată grațierea lor, iar sporul de pedeapsă se înlătură. În consecință, pedepsele existente la data săvârșirii celei de-a doua infracțiuni fiind mai mici de 6 luni, ele nu mai pot fi avute în vedere la stabilirea stării de recidivă" (s.n.).

65 Pentru mai multe detalii cu privire la diferența de tratament sancționator între cele două forme de pluralitate de infracțiuni, a se vedea G. Bodoroncea în Codul penal. Comentariu pe articole, ediția 3 (colectiv), Ed. C.H. Beck, București, 2020, pp. 253 și urm.
} 
vom preciza încă de pe acum că nu ni se pare o soluție echitabilă și de dorit în practică aceea a înlăturării stării de recidivă prin intermediul unui act normativ de grațiere.

Atâta timp cât doctrina de drept penal converge spre o singură interpretare în materia efectelor grațierii, soluția pe care o considerăm corectă trebuie să respecte aceste cerințe. Așa cum am anticipat deja de-a lungul lucrării, considerăm ca fiind corectă practica instanțelor judecătorești care au stabilit pedepsele din concurs fără a ține seama de actul de grațiere antecondamnatorie și care au calculat pedeapsa rezultantă ca și cum grațierea nu ar fi existat. În continuare, pentru o mai bună înțelegere vom denumi această pedeapsă ca fiind pedeapsa condamnatorie ${ }^{66}$ (pedeapsa de condamnare). Ulterior calculării acesteia, instanța trebuie să descontopească pedepsele și să constate grațierea totală sau parțială a celor care fac obiectul actului de clemență, urmând să calculeze o altă pedeapsă rezultantă pe care o va avea efectiv de executat condamnatul. Această pedeapsă o vom numi pedeapsa executorie ${ }^{67}$ (pedeapsa de executare sau de executat).

În acest fel, consecințele condamnării (printre care se regăsește și recidiva ${ }^{68}$ ) se vor raporta doar la durata pedepsei condamnatorii, iar partea de executare efectivă a pedepsei se va raporta doar la durata pedepsei executorii calculate de către instanța de judecată. După cum se poate vedea, această soluție presupune ca în cadrul hotărârii definitive de condamnare instanța să calculeze și să evidențieze, în mod separat, două pedepse rezultante ${ }^{69}$.

\section{Argumente în favoarea soluției propuse}

Conform opiniei profesorului Dongoroz, „sancțiunea, statornicită de instanțele judecătorești, trebue să rămână ceva definitiv și irevocabil, din punct de vedere judiciar, nu însă și din punct de vedere al executării sancțiunii"70.

Având în vedere cele expuse la punctul anterior, este necesară argumentarea juridică a unei asemenea soluții pe care instanțele de judecată considerăm că trebuie să o adopte în cadrul problemei de drept evidențiate. Acest lucru va contraveni, în mod implicit, soluției instanței supreme în această materie din Decizia nr. X(10)/2005.

\footnotetext{
${ }^{66}$ Această denumire reflectă pedeapsa la care inculpatul este condamnat de către instanță și pe care acesta ar fi executat-o dacă nu ar fi intervenit actul de clemență.

67 Această denumire reflectă pedeapsa pe care o va avea efectiv de executat condamnatul, luând în calcul efectele legii de grațiere.

${ }^{68}$ Sau, mai precis, posibilitatea unei eventuale încadrări în condițiile recidivei.

${ }^{69} \mathrm{Ca}$ exemplu, dispozitivul unei asemenea hotărâri de condamnare ar putea arăta în felul următor:

1. Instanța, în temeiul art. 38 alin. (1) C.pen. și art. 39 alin. (1) lit. b) C.pen., contopește pedeapsa de X ani închisoare și pedeapsa de $Y$ ani închisoare, aplicând inculpatului pedeapsa cea mai grea de $X$ ani închisoare, la care se adaugă un spor de $1 / 3$ din suma celorlalte pedepse cu închisoarea, rezultând în total Z ani închisoare (pedeapsa condamnatorie).

2. Se constată grațierea antecondamnatorie totală a pedepsei de $Y$ ani închisoare.

3. Descontopește pedeapsa rezultantă de la punctul 1 și recalculează o nouă pedeapsă, de X ani închisoare (pedeapsa executorie).

4. În final, instanța îl condamnă pe inculpat la pedeapsa de Z ani închisoare, urmând a avea efectiv de executat o pedeapsă de $X$ ani închisoare.

${ }^{70}$ V. Dongoroz, op. cit., p. 555.
} 


\section{A. Revocarea grațierii condiționate}

În unele cazuri, în interiorul actului de grațiere colectivă se poate preciza că vor beneficia de iertarea de pedeapsă doar acele persoane care într-un anumit interval de timp nu vor mai comite alte infracțiuni. Dacă respectiva persoană nu respectă această condiție, acesteia i se va revoca beneficiul măsurii de clemență. Astfel, va urma ca instanța de judecată să revină asupra pedepsei inițiale la care l-a condamnat pe inculpat, iar acesta să execute această pedeapsă, fără nicio altă micșorare a acesteia ${ }^{71}$. După cum bine precizează un autor, „dat fiind că numărul beneficiarilor actelor de clemență care au săvârșit din nou infracțiuni intenționate înăuntrul termenului-condiție nu este deloc neglijabil, apreciem că revocarea grațierii condiționate a încetat să mai reprezinte un eveniment excepțional ${ }^{\prime 72}$.

După cum se poate vedea, în cazul revocării grațierii instanța trebuie să cunoască ce pedeapsă i-ar fi aplicat inculpatului dacă nu ar fi intervenit actul de clemență. Dacă aceasta ar calcula pedeapsa rezultantă a unui concurs de infracțiuni în funcție de soluția propusă de î.C.C.J. în Decizia X(10)/2005, ar fi obligată să revină asupra stabilirii pedepsei care fusese grațiată total sau parțial și să calculeze din nou pedeapsa rezultantă. În schimb, dacă ar da efecte soluției propuse la punctul anterior, ulterior revocării grațierii condiționate instanța ar da aplicare în mod direct pedepsei condamnatorii, scăzând eventuala parte executată din aceasta.

La o primă vedere, se poate afirma că nu există nicio diferență între situația în care instanța calculează ulterior revocării grațierii pedeapsa rezultantă fără a lua în calcul măsura de clemență și aceea în care instanța o calculează astfel de la data pronunțării hotărârii definitive de condamnare. Totuși, după cum vom arăta în cele de mai jos, prin intermediul principiului autorității de lucru judecat se creează o diferență evidentă între aceste două situații.

\section{B. Autoritatea de lucru judecat a instanței care îl condamnă definitiv pe inculpat}

Potrivit art. 393 alin. (2) C.pr.pen. ${ }^{73}$, „deliberarea poartă asupra existenţei faptei şi vinovăţiei inculpatului, asupra stabilirii pedepsei, asupra stabilirii măsurii educative ori măsurii de siguranţă, dacă este cazul să fie luată, precum şi asupra deducerii duratei măsurilor preventive privative de libertate şi a internării medicale". Așadar, în cazul concursului de infracțiuni, instanța de judecată este obligată să stabilească, pentru fiecare infracțiune în parte, pedeapsa cuvenită și ulterior să calculeze pedeapsa rezultantă. Legiuitorul a ținut să precizeze în mod expres acest lucru, deoarece doar instanța care îl condamnă definitiv pe inculpat cunoaște în cele mai precise detalii criteriile particulare de individualizare aplicabile în respectiva speță. Acest fapt conduce și la respectarea principiului individualizării depline a pedepsei.

Autoritatea de lucru judecat reprezintă mai mult decât obligativitatea stabilirii pedepsei pentru fiecare infracțiune din concurs. Prin intermediul acestui deziderat inculpatului i se satisface și dreptul de a înțelege de la bun început la ce pedeapsă va fi

\footnotetext{
${ }^{71}$ Pentru mai multe detalii, a se vedea I. Mândru, op. cit., pp. 404-408.

72 Idem, p. 402.

${ }^{73}$ Adoptat prin Legea nr. 135/2010, publicată în M. Of. nr. 486 din 15 iulie 2010, cu modificările și completările ulterioare.
} 
condamnat și la ce consecințe juridice va duce aceasta. În acest fel, acesta va cunoaște dacă se va afla sau nu în stare de recidivă în urma unei eventuale săvârșiri a unei infracțiuni intenționate, conducând astfel și la respectarea principiului prevenției speciale $e^{74}$.

În concluzie, pentru buna funcționare a autorității de lucru judecat și a prevenției speciale, credem că este indicat ca instanța care pronunță hotărârea definitivă de condamnare să stabilească pedepsele și ulterior să calculeze și pedeapsa rezultantă a concursului fără a lua în seamă existența grațierii antecondamnatorii. Astfel, se va respecta și dreptul de informare al inculpatului cu privire la consecințele condamnării definitive.

\section{Verificarea condiției privind durata pedepsei aplicate de către instanță}

Potrivit dispozițiilor din materia cauzelor care înlătură consecințele condamnării, atât termenul reabilitării de drept, cât și cel al reabilitării judecătorești se calculează în funcție de pedeapsa la care a fost condamnat inculpatul, făcând abstracție de eventualele cauze de modificare a acesteia ${ }^{75}$. Pe de altă parte, în materia prescripției executării pedepsei, art. 162 alin. (7) C.pen. prevede în mod expres faptul că „prin pedeapsa ce se execută se înțelege pedeapsa stabilită de instanță, ținându-se cont de cauzele ulterioare de modificare a acesteia" (dintre care face parte și grațierea - n.n.) ${ }^{76}$.

Este important de subliniat faptul că această ultimă dispoziție este una de excepție. Drept urmare, în cazurile în care legiuitorul de drept penal a dorit ca verificarea condițiilor privind durata pedepsei aplicate să se raporteze și la eventualele cauze de modificare a acesteia, acest lucru se va preciza în mod expres.

în acest sens, în cadrul art. 41 alin. (1) C.pen. se menționează doar că primul termen al recidivei se va raporta la pedeapsa la care inculpatul a fost condamnat, fără a se sublinia ceva în legătură cu cauzele ulterioare de modificare a acesteia. Așadar, în materia recidivei, la verificarea condiției privind durata pedepsei aplicate ar trebui să nu se țină cont de efectele produse de către un act de grațiere antecondamnatorie.

\section{Condamnările care nu atrag starea de recidivă și analiza unor ipoteze particulare}

În cadrul art. 42 C.pen. sunt reliefate condamnările care nu atrag starea de recidivă, și anume cele privitoare la: faptele care nu mai sunt prevăzute de legea penală, infracțiunile amnistiate și infracțiunile săvârșite din culpă. Fiind o dispoziție care cuprinde o enumerare exhaustivă, aceste situații sunt de strictă interpretare față de celelalte tipuri de condamnări. În acest sens, trebuie făcută delimitarea clară între efectele produse de aceste instituții de drept și grațiere.

\footnotetext{
${ }^{74}$ A. Cocaină, op. cit., p. 60.

75 A se vedea I. Nedelcu în Codul penal. Comentariu pe articole, ediția 3 (colectiv), Ed. C.H. Beck, București, 2020, p. 621. Autoarea afirmă că „termenul de reabilitare se calculează în funcție de pedeapsa ce face obiect al condamnării, de pedeapsa pronunțată de instanță, iar nu în funcție de pedeapsa redusă”.

${ }^{76}$ Așadar, termenele privind reabilitarea de drept și cea judecătorească se vor calcula în funcție de durata pedepsei condamnatorii, iar termenele de prescripție a executării pedepsei se vor raporta la durata pedepsei executorii.
} 
Amnistia și dezincriminarea au ca obiect infracțiunea și existența efectivă a acesteia $^{77}$. În cazul acestora, acțiunea penală nu poate fi pusă în mișcare, iar dacă a fost pusă nu va mai putea fi exercitată ${ }^{78}$. Tot astfel, doctrina a realizat o comparație care clarifică, din punct de vedere al efectelor asupra stării de recidivă, diferența între aceste instituții și instituția grațierii. În acest fel, s-a precizat că „sporul dispare în cazul în care o infracțiune din cele două, aflate în concurs, este dezincriminată sau amnistiată și, prin urmare, în situația menționată, nu va putea fi reținută starea de recidivă. În schimb, sporul va fi numai înlăturat în cazul grațierii" ${ }^{\prime 79}$ (s.n.).

Utilizând soluția considerată de î.C.C.J. ca fiind corectă, grațierea antecondamnatorie va face ca partea din pedeapsă ce a făcut obiectul actului de clemență să dispară în totalitate. Drept urmare, sub aspectul reținerii stării de recidivă, efectele dezincriminării, amnistiei și grațierii vor ajunge să se confunde. Cu toate acestea, pentru a vedea dacă o soluție de acest tip este fiabilă, ar fi utilă o comparație și cu alte situații particulare care pot fi întâlnite în practică.

(a) Ipoteza unei singure infracțiuni săvârșite, care este grațiată antecondamnatoriu. Soluția la care s-a oprit î.C.C.J. în Decizia X(10)/2005 are consecințe doar în cazul în care grațierea antecondamnatorie intervine asupra unei pedepse stabilite pentru o infracțiune aflată în concurs. În situația în care acest tip de grațiere ar avea ca obiect o singură pedeapsă care nu se află în vreo formă de pluralitate de infracțiuni, se pune întrebarea dacă grațierea va avea aceleași efecte ca în cazul ipotezei din decizia instanței supreme (și anume, dacă pedeapsa la care va fi condamnat inculpatul va fi cea micșorată potrivit actului de clemență).

De această dată, considerăm că nu mai există nicio justificare legală care să permită instanței să-I condamne pe inculpat la o pedeapsă mai mică datorită grațierii anticipate. După cum am mai arătat, grațierea antecondamnatorie își va produce efectele doar de la data pronunțării hotărârii definitive de condamnare, având aceleași efecte ca și cum ar fi intervenit postcondamnatoriu.

(b) Ipoteza unei grațieri postcondamnatorii. În situația concursului de infracțiuni, „dacă pentru unele dintre aceste pedepse este incidentă grațierea (fiind vorba de o grațiere postcondamnatorie - n.n. $)^{80}$, ele vor fi descontopite, iar dacă a rămas o singură pedeapsă din pedeapsa rezultantă, care nu este grațiată, va fi înlăturat și sporul eventual aplicat"81. Astfel, grațierea postcondamnatorie nu va putea modifica pedeapsa rezultantă la care inculpatul a fost condamnat de către instanță. În această situație, instanța care va judeca contestația la executare ${ }^{82}$ va trebui să calculeze o nouă pedeapsă rezultantă pe care o va avea de executat efectiv condamnatul, scăzând, în mod firesc, ce a executat până la zi. Drept urmare, condițiile termenului I al recidivei se vor raporta nu la această ultimă pedeapsă, ci la pedeapsa aplicată de către prima instanță care I-a condamnat. Se poate observa că în cazul acesta, ca și în soluția propusă de noi, vor exista două pedepse distincte. Una dintre acestea

\footnotetext{
77 După cum am mai precizat, grațierea are ca obiect pedeapsa.

78 Prevedere expresă în art. 16 C.pr.pen.

79 I. Mândru, op. cit., p. 430.

80 Ibidem.

${ }^{81}$ Art. 14 alin. (2) din Legea nr. 546/2002.

82 Potrivit art. 598 alin. (1) lit. d) C.pr.pen., contestația împotriva executării hotărârii penale se poate face atunci când se invocă amnistia, prescripția, grațierea sau orice altă cauză de stingere sau de micșorare a pedepsei.
} 
va funcționa strict ca pedeapsă pentru care a fost condamnat inculpatul și alta strict pentru executarea efectivă a sancțiunii penale.

(c) Ipoteza unei grațieri antecondamnatorii prin intermediul căreia pedeapsa a fost comutată. Actul de clemență poate prevedea în cuprinsul acestuia faptul că pedepsele cu o anumită durată de închisoare se vor înlocui cu pedeapsa amenzii penale. În cazul infracțiunii care reprezintă primul termen al recidivei este necesar ca instanța de judecată să fi aplicat o pedeapsă cu închisoarea mai mare de un an sau detențiunea pe viață83. Drept urmare, dacă a fost aplicată sancțiunea amenzii penale, această pedeapsă ar putea reprezenta un eventual termen I al unei pluralități intermediare.

Termenul I al recidivei poate fi constituit și dintr-o pedeapsă rezultantă, cu condiția ca aceasta să fie mai mare de un an, chiar dacă pedepsele, în individualitatea lor, nu îndeplinesc această cerință ${ }^{84}$. Conform art. 39 alin. (1) lit. d) C.pen., "atunci când s-a stabilit atât o pedeapsă cu închisoarea, cât și o pedeapsă cu amendă, se aplică pedeapsa închisorii, la care se adaugă în întregime pedeapsa amenzii" (cumul aritmetic - n.n.). Acceptând soluția instanței supreme din Decizia RIL X(10)/2005, în cazul comutării unei pedepse din concurs din pedeapsa închisorii în cea a amenzii penale, se observă că există posibilitatea ca pedeapsa rezultantă să devină mai mică sau egală cu un $a n^{85}$. Aceasta va depinde, în primul rând, de pedeapsa care nu a făcut obiectul grațierii (în sensul în care, instanța stabilise pentru aceasta o pedeapsă mai mică sau egală cu un an).

Ne punem întrebarea dacă o asemenea situație ar putea fi acceptată în practică. Avem în vedere în acest sens faptul că, ulterior individualizării pedepsei, instanța de judecată ar fi stabilit pentru toate pedepsele sancțiunea închisorii și nu pe cea a amenzii. Astfel, inculpatul ar fi fost condamnat la o pedeapsă rezultantă care, cel mai probabil, ar fi îndeplinit condiția privind pedeapsa aplicată din cadrul recidivei.

În vreme ce executarea efectivă a pedepsei închisorii poate fi înlocuită cu amenda, nu credem că verificarea condiției privind pedeapsa aplicată de la primul termen al recidivei trebuie să se grefeze pe această comutare. Ceea ce contează în cadrul consecințelor condamnării nu este ceea ce va executa efectiv inculpatul, ci este reprezentat de pedeapsa pe care instanța o consideră adecvată ansamblului infracțional. Astfel, potrivit opiniei profesorului Dongoroz, "adaptarea sancțiunilor în faza executării nu implică, deci, schimbarea condamnațiunii, ci schimbarea condițiunilor în care se va executa sancțiunea și a momentului când executarea trebue să fie socotită ca suficientă" ${ }^{\prime 86}$.

Este curios faptul că prin modalitatea de sancționare a concursului din Decizia X(10)/2005 a î.C.C.J. se dă frâu liber și motivație condamnaților de a comite și alte infracțiuni, știind că li se va aplica un tratament sancționator mai ușor, și nu cel din cadrul recidivei. Prin urmare, în fiecare situație prezentată mai sus considerăm ca fiind cel mai potrivit ca instanțele de judecată să respecte raționamentul soluției propuse în prezenta lucrare pentru a da aplicare, în mod corect, efectelor pe care le poate produce grațierea.

\footnotetext{
${ }^{83}$ Art. 41 alin. (1) C.pen. Pentru mai multe detalii, a se vedea F. Streteanu, D. Nițu, op. cit., vol. II, pp. 146-149; L.V. Lefterache, op. cit., p. 386.

${ }^{84}$ A se vedea F. Streteanu, D. Nițu, op. cit., vol. II, p. 147, pct. 741.

85 Trebuie menționat că există chiar posibilitatea ca toate pedepsele aflate în concurs să facă obiectul comutării. În mod evident, în acest caz condițiile termenului I al recidivei nu mai pot fi îndeplinite.

${ }^{86}$ V. Dongoroz, op. cit., p. 555.
} 


\section{Comparație cu situația individualizării judiciare a executării pedepsei}

Individualizarea judiciară a executării pedepsei constă în obligația instanței de judecată de a particulariza modul în care inculpatul va executa pedeapsa stabilită. Fiecare dintre instituțiile care fac parte din această clasificare a individualizării pedepsei ${ }^{87}$ conțin diferite condiții pentru ca instanța să le poată aplica. Una dintre condițiile care interesează pentru realizarea unei comparații cu condițiile recidivei are ca obiect durata pedepsei aplicate de către instanță. în acest sens, se instituie pentru fiecare dintre acestea o anumită durată maximă a acestei pedepse ${ }^{88}$. Ca și în cazul recidivei, nu se va ține seama dacă pedeapsa a fost stabilită pentru o singură infracțiune sau pentru un concurs de infracțiuni. În ambele cazuri, este necesar ca pedeapsa rezultantă să se încadreze în limitele legale impuse. Din aceste considerente rezultă faptul că modalitatea de contopire a pedepselor din concurs va fi aceeași în ambele situații.

Astfel, trebuie analizat dacă în cazul acestor condiții instanța va ține cont de actul de grațiere antecondamnatorie, așa cum a statuat jurisprudența î.C.C.J. în materia concursului de infracțiuni. Mai mult, potrivit celor arătate mai sus ${ }^{89}$, legiuitorul ar fi trebuit să precizeze în mod expres dacă pentru îndeplinirea duratei pedepsei aplicate se va ține cont și de cauzele de modificare a acesteia.

Pe lângă acest fapt, o scurtă analiză a jurisprudenței în materie a fostei instanțe supreme credem că prezintă interes. În acest sens, fosta Curte Supremă de Justiție a decis că, „în caz de grațiere parțială a pedepsei, pentru suspendarea executării se are în vedere pedeapsa aplicată, iar nu restul de pedeapsă rămas negrațiat. Ca urmare, dacă pedeapsa aplicată depășește limitele prevăzute de art. 81 și art. 86 C.pen. (Codul penal din 1969 n.n. $)^{90}$, nu se poate dispune suspendarea executării, chiar dacă restul rămas de executat în urma grațierii parțiale nu depășește aceste limite"g1 (s.n.).

Chiar dacă această decizie a fost pronunțată pentru instituțiile individualizării executării pedepsei din Codul penal din 1969, considerăm că aceasta se va aplica în continuare și pentru actualele instituții din Noul Cod penal. După cum se poate observa, problema este că cele statuate în Decizia RIL X(10)/2005 conferă o altfel de interpretare în legătură cu modalitatea de verificare a condiției privind pedeapsa aplicată de către instanță în caz de grațiere. După părerea noastră, nu vedem nicio distincție între modalitatea de calcul a pedepsei aplicate la primul termen al recidivei și cea a pedepsei aplicate în cazul instituțiilor individualizării judiciare a executării pedepsei. Așadar, credem că raționamentul fostei instanțe supreme din jurisprudența precitată este corect (respectând efectele legale ale grațierii și ale concursului de infracțiuni) și ar trebui aplicat și în cazul verificării condiției termenului I al recidivei.

87 Fac parte din cadrul acestei clasificări: renunțarea aplicării pedepsei, amânarea aplicării pedepsei, suspendarea executării pedepsei sub supraveghere și liberarea condiționată. Pentru o analiză, pe larg, a acestor instituții, a se vedea L.V. Lefterache, op. cit., pp. 442 și urm.

88 În acest sens, a se vedea dispozițiile art. 80, 83, 91, 99 și 100 C.pen.

${ }^{89}$ A se vedea supra, p. 16.

90 Dispoziții care se refereau la condițiile suspendării condiționate și ale suspendării sub supraveghere.

${ }^{91}$ A se vedea C.S.J., Secția penală, decizia nr. 2452/2001, pronunțată în aplicarea Codului penal anterior, apud R. Moroșanu, op. cit., p. 30. Instanța supremă a statuat că „instanţa de recurs a aplicat greşit prevederile art. $86^{1} \mathrm{C}$. pen., potrivit cărora suspendarea executării nu se poate dispune dacă pedeapsa aplicată depăşeşte 4 şi, respectiv, 3 ani închisoare. Textul de lege menţionat se referă la pedeapsa aplicată de instanţă, în speţă 5 ani închisoare, iar nu la pedeapsa rezultată în urma graţierii parţiale, de 2 ani şi 6 luni, cum este cazul în speţă". 


\section{CONSIDERAṬII FINALE}

Toate cele expuse în lucrarea de față conferă o imagine sumară a jurisprudenței și a doctrinei care s-au aplecat asupra efectelor pe care grațierea le produce. Cu toate că, în genere, grațierea a fost încadrată în cauzele care înlătură exclusiv sancțiunea aplicată, aceasta a cunoscut și anumite interpretări mai extinse. Posibilitatea de a deveni o piedică în sancționarea concursului de infracțiuni și în constatarea recidivei este una dintre interpretările cele mai controversate. După cum am arătat, prin intermediul Deciziei RIL X(10)/2005 se pare că instanța supremă a considerat că măsurile de clemență intervenite înaintea unei hotărâri definitive de condamnare ar putea produce asemenea consecințe juridice.

Pentru a respecta în integralitate efectele produse de grațiere, soluția propusă în lucrarea de față constă în calcularea în mod separat, în cadrul hotărârii definitive de condamnare, a două pedepse rezultante. În primul rând, instanța ar trebui să calculeze pedeapsa condamnatorie, asupra căreia se va grefa condiția privind durata pedepsei concret aplicate de către instanță în cazul infracțiunii care constituie primul termen al eventualei recidive. În al doilea rând, aceasta trebuie să calculeze și pedeapsa executorie, pe care o va avea de executat efectiv condamnatul. În acest mod, se va da aplicare efectelor grațierii și a condițiilor actuale din materia recidivei și sancționării concursului de infracțiuni. Astfel, nu va mai exista posibilitatea ca grațierea antecondamnatorie să confere un beneficiu dublu ${ }^{92}$ inculpatului, care apare ca fiind nejustificat din perspectiva efectului produs asupra recidivei. Totodată, de lege ferenda, credem că ar fi bine-venită o nouă revizuire a Legii nr. 546/2002, având în vedere unele aspecte necoroborate cu actualele dispoziții din Noul Cod penal.

În sensul arătat, considerăm că Decizia RIL X(10)/2005 a Î.C.C.J. este de actualitate din perspectiva sancționării concursului de infracțiuni în caz de grațiere anticipată, doar în cazul în care va fi folosită pentru calcularea pedepsei rezultante pe care o va avea efectiv de executat inculpatul. Credem că aceasta este foarte utilă în acest sens, dar este necesar ca instanțele să nu o utilizeze și în ipoteze pentru care nu a fost pronunțată.

În concluzie, rămâne de văzut ce se va întâmpla la nivelul practicii judiciare în cazul viitoarelor acte normative de grațiere și care va fi soluția instanțelor cu privire la interpretarea acestei jurisprudențe a instanței supreme. Din punct de vedere legal însă, considerăm că instanțele au suficiente linii directoare pentru a aplica cea mai înțeleaptă soluție în problema de drept evidențiată.

\footnotetext{
92 Prin beneficiu dublu înțelegem atât remiterea de executare a pedepsei, cât și înlăturarea unei eventuale încadrări în condițiile recidivei.
} 